UDC 620.179

\title{
INFLUENCE OF PH RATE ON CORROSION OF GAS PIPELINES IN SOILS WITH HIGH MINERALIZATION
}

\section{Lubomyr Poberezhny; Andrii Hrytsanchuk; Nataliia Halushko; Liubov Poberezhna}

\author{
Ivano-Frankivsk National Technical University of Oil and Gas, \\ Ivano-Frankivsk, Ukraine
}

\begin{abstract}
Summary. An anomalous increase in the soil electrolyte corrosive activity was detected due to the synergistic cumulative action of the corrosion-active components present in determined ratios of ionic molar concentrations The obtained results allow us to better evaluate operational risks and to predict the life length and usable lifespan of the safe oil and gas pipeline operation, as well as to prevent a significant number of pipeline failures at the engineering design and production activity.
\end{abstract}

Key words: gas pipeline, corrosion degradation, corrosion rate, highly mineralized soils, soil acidity.

https://doi.org/10.33108/visnyk_tntu2019.03.041

Received 15.09.2019

Statement of the problem. Various physicochemical and soil-climatic factors affect downhole oil-and-gas pipelines and comprehensively define operating conditions. The complexity of the interaction of these time-dependent variables leads to the fact that the specific combinations can result in acceleration and deceleration of the corrosion process.

Conducted researches of downhole oil-and-gas pipelines have shown that the production life index mainly depends on the fundamental metal and welded pipe joint corrosion resistance, as well as on the form of the metal surface fracture in regions with faulted out seal coat.

Analysis of the available investigations. Problems of pipelines and soil interaction have not been sufficiently studied in the construction practice. Therefore, there are no defined and proven methods of the selection or calculation of the main characteristics for the following calculation and analysis of downhole pipeline work [1].

Considering the corrosive activity of the soil, which is customary to evaluate time before the appearance of the first cavern in the new pipeline, the composition and physical and mechanical properties of soils and their dynamics significantly complicates the calculation scheme, since there are many additional time-varying parameters that are taken not only from, but are also experimentally determined. The list of the most important factors that determine the corrosive activity of soils, such as structure and particle size distribution, moisture content, soil electrolyte composition, total acidity or alkalinity of soil, hydrogen ion concentration, air permeability, redox potential, electrical resistivity, electrical resistance modeling of deformable system «pipe - soil massif» and, accordingly, prediction of durability of underground pipeline [2-3].

It is believed that the behavior of the steel pipeline in soils in many ways is similar to its behavior when fully immersed in solutions with the appropriate $\mathrm{pH}$. At the same time, the electrochemical mechanism of corrosion with the formation of micro-galvanic elements prevails. However, in the underground pipeline, due to the heterogeneity of the pipe metal and the heterogeneity of the soil in terms of both physical properties and chemical composition, as well as different aeration, there are areas where the electrode potential is markedly different, which causes the formation of macrogalvanic corrosion. Pipeline sections with more negative 
potential become anodic, and sections with less negative potential become cathodic [4-6].

Downhole mainland pipelines made of $17 \mathrm{G} 1 \mathrm{SU}$ were selected as the model for this research. Flat samples were constructed from the material of the different sections of the linear pipeline part using the technology developed in IFNTUOG [7-8].

The objective of the work is to establish the corrosion patterns of underground gas pipelines in highly mineralized s oils with different $\mathrm{pH}$ levels.

Statement of the task. The chemical decomposition of soil electrolytes has been analyzed. Based on that, it was suggested 6 different simulative environments for corrosion tests (see Table 1), which can be formally divided into chloride sulfate (ME 1-3) and acidified chloride sulfate (ME 4-6). Such type of soil electrolytes is located in areas with high soil salinity.

In the first stage of testing, the corrosion behavior of the chloride-sulfate pipeline steel (ME1 - ME3) was studied.

Table 1

Chemical composition of solutions for the corrosion tests

\begin{tabular}{|c|c|c|c|}
\hline \multirow{2}{*}{ № $\mathrm{ME}$} & \multicolumn{3}{|c|}{ Concentration, $\mathrm{mol} / \mathrm{l}$} \\
\cline { 2 - 4 } & $\mathrm{NaCl}$ & $\mathrm{Na}_{2} \mathrm{SO}_{4}$ & $\mathrm{H}_{2} \mathrm{SO}_{4}$ \\
\hline 1 & 0,005 & 0,005 & - \\
\hline 2 & 0,025 & 0,025 & - \\
\hline 3 & 0,05 & 0,05 & 0,000005 \\
\hline 4 & 0,005 & 0,005 & 0,00005 \\
\hline 5 & 0,025 & 0,025 & 0,0005 \\
\hline 6 & 0,05 & 0,05 & \\
\hline
\end{tabular}

Results and discussion. Researches have shown (Fig. 1,2) the increase of the intensity of corrosion decline in all three environments for both general and local corrosion. Such results are approved by electrochemical tests of corrosion currents of anode and cathode dissolution, as well as the kinetics of electrode potential (EP) [9].
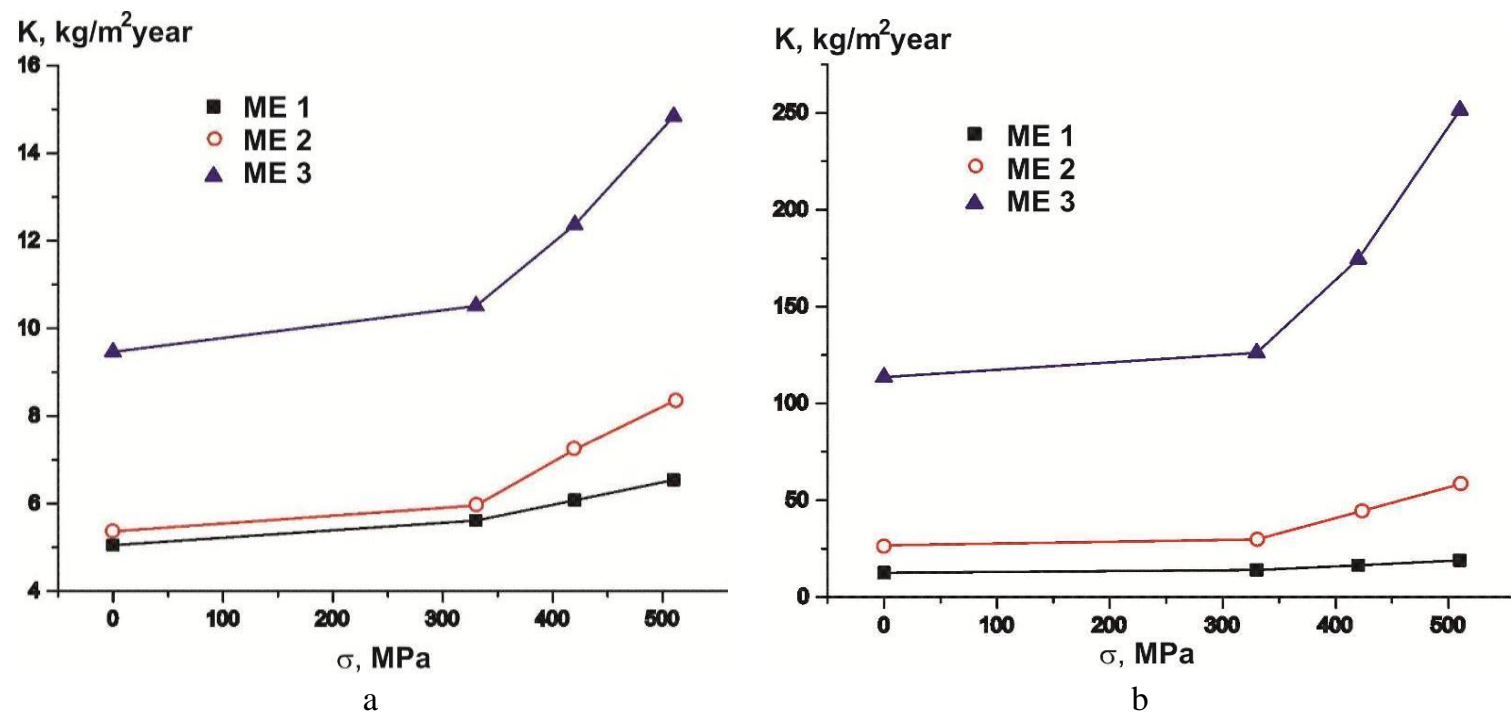

Figure 1. The dependence rate of corrosion in chloride-sulfate electrolytes on the level of mechanical loads and chemical composition of the environment ( $\mathrm{a}$ - general corrosion, $\mathrm{b}-$ local corrosion) 
The rates of general and local corrosion increase with the growth of the ionic strength. This correlation is prevalent in the transition from ME2 to ME3. It should be noticed that such a cumulative synergistic action of sulfate and chloride ions was detected for the first time. Such an important conclusion can be drawn from Figure $1 \mathrm{a}$ and Figure $1 \mathrm{~b}$ by comparing corrosion curves and the corrosion accelerated rate during the transition from ME1 to ME2 and ME2 to ME3. We observe a significant difference not only in the accelerated rate but also in the increase of the intensity of corrosion decline with the increase of mechanical loads in the zone of elastoplastic deformation. The last tendency can also be pointed out during the transition from ME1 to ME2, but its intensity is much lower.

The revealed hazardous patterns force us to do the more accurate calculation of the thinning of the pipeline wall with proportional and local corrosion in chloride-sulfate environments.

Studies show (Fig. 2) that in the field of operational loads, the rate of total corrosion is about $0.6 \mathrm{~mm} /$ year for ME1 and ME2, for ME3 more than $1 \mathrm{~mm} /$ year, which again confirms the extreme danger of this ionic ratio concentrations. Such rate, even in the case of the safest option of the environment (ME1), indicates the necessity of reexamination of the existing estimated resources and the usable lifespan of the safe oil and gas pipelines operation in the areas of saline soils. In the case of detecting the ratios of ionic concentrations like in ME3, it requires major detailed analysis of passive and active corrosion protection and determination of its damage rate, as well as the pipeline material damage rate using methods of nondestructive testing and in-line inspection. The areas of potential additional mechanical loads should be monitored carefully. First of all, we have to consider landslides in mountainous areas, underground crossings through railways and roads, etc.
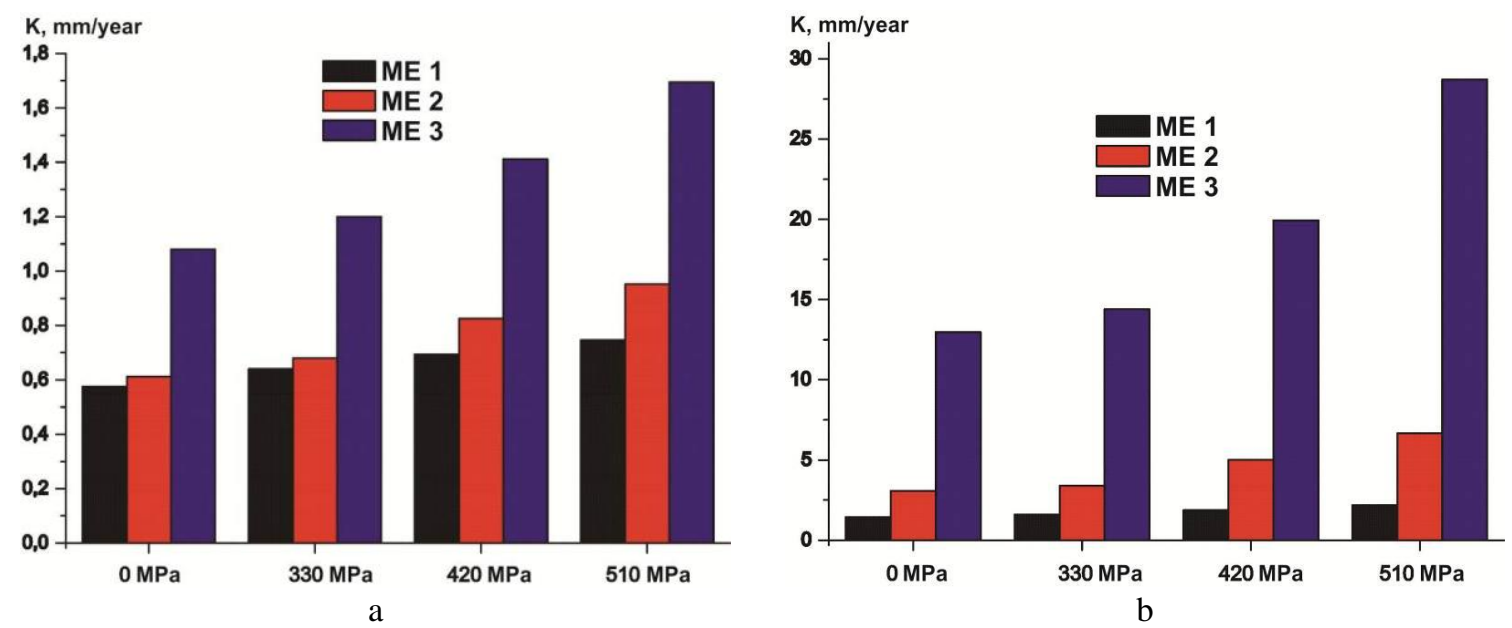

Figure 2. Thinning of the pipe wall in chloride-sulfate electrolytes ( $\mathrm{a}$ - general corrosion, $\mathrm{b}$ - local corrosion)

Assessment of the localization of corrosion processes in all chloride-sulfate ME showed significant local content, but in ME3 abnormal corrosion behavior occurred once again. Not only an abnormally high corrosion rate at a given ionic concentration ratio was found for the first time, but also an abnormally intense local content of corrosion processes. As a result, the local corrosion rate in the field of mechanical loads can exceed $12 \mathrm{~mm} /$ year.

Ground electrolytes should be examined as soon as possible along the pipeline routes, especially those which experience the depletion of the planned life length. The obtained results 
show that, if the protective coating is damaged and the active corrosion protection is not properly utilized, their operation in areas with the dangerous ratio of ionic concentrations can cause serious accidents and catastrophes with hard-to-predict consequences for the population and the environment.

In the second stage, we studied the influence of the $\mathrm{pH}$ environment on the corrosion behavior of the steel pipeline in chloride-sulfate electrolytes (ME4-ME6).

As it was in acidified chloride electrolytes, we could observe a pattern of fluctuation of corrosion behavior (Fig. 3, 4).

At $\mathrm{pH} 5$, in the range of operational loads, we observe a slight monotonic increase of the rate of total corrosion at an almost constant local rate. However, in the field of elastic deformation, we notice a significant activation of local corrosion processes, as well as a significant general corrosion rate growth. This corrosive behavior is associated with a significant tendency to locate corrosion processes in chloride-sulfate environments. In the range of high loads, local corrosion damages are considered to be crucial areas such as load concentrators, in which local galvanic elements (GE) of a concentric nature begin to form and accelerate corrosion processes, as well as GE from EMF, which is emitted by the difference between the potentials of the outer casing of the metal and the bottom of corrosion pit .

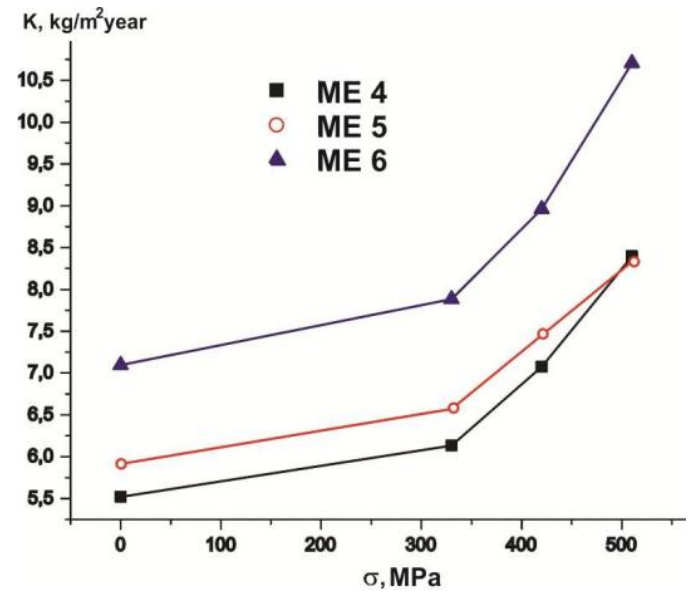

a



$\mathrm{b}$

Figure 3. The dependence of the rate corrosion in acidified chloride-sulfate electrolytes on the level of mechanical loads and chemical composition of the environment ( $\mathrm{a}$ - general corrosion, $\mathrm{b}$ - local corrosion)

Their periodic origin is proved by the first saltatory changes of the EP [10].

At pH4 we register a significant increase (about 15\%) of the total corrosion rate and a significant (about 40\%) intensification of the local content of corrosion processes. The last one, apparently, as in the case of acidified chloride environments, is associated with a change in the mechanism of depolarization and its simultaneous passage through both mechanisms.

At PH3 we can observe an abnormally low (compared to non-acidic (ME6) environment) rate of both general and especially local corrosion. 

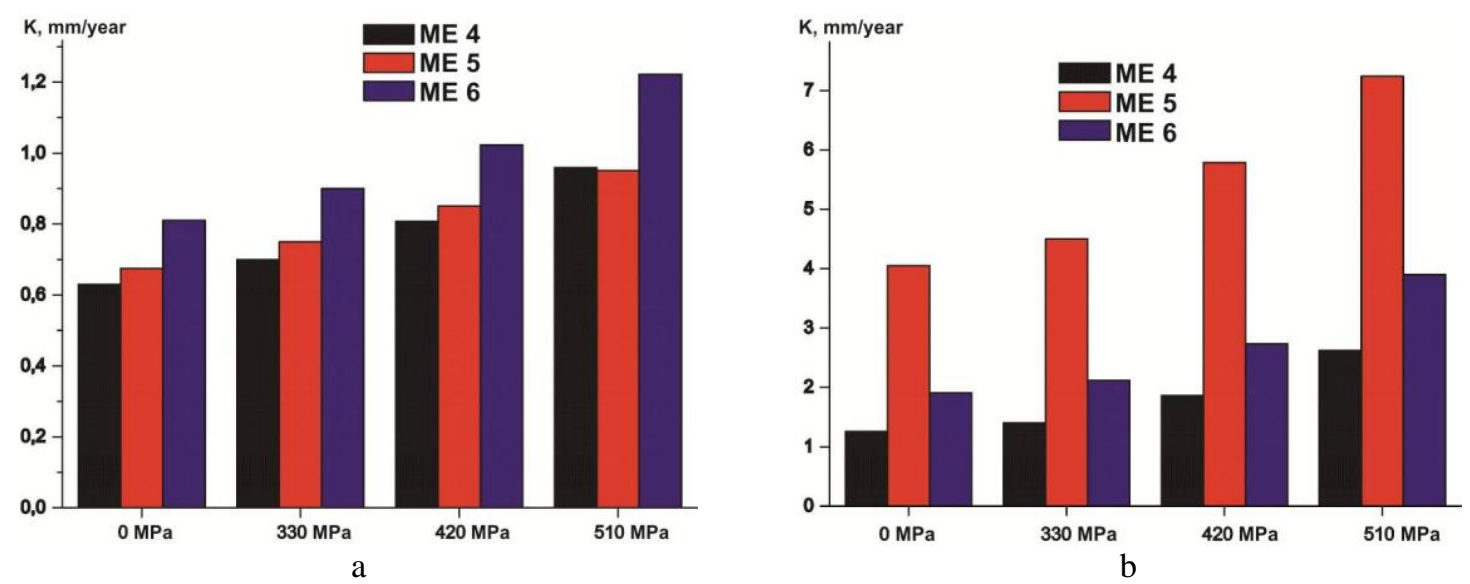

Figure 4. Thinning of the pipe wall in acidified chloride-sulfate electrolytes ( $\mathrm{a}$ - general corrosion, $\mathrm{b}$ - local corrosion)

This situation is partly caused by, as in the case of acidified chloride media, a change in the mechanism of depolarization, and therefore the course of corrosion processes. However, the change of the firstly detected ratio of ionic concentration is the most important because it causes extreme synergies and cumulative effects of corrosion, mechanical and specific ionic factors. Such an explanation is practically the only one which is possible, since the qualitative ionic composition of the environment remains still, and the material of the pipeline and the magnitudes of applied mechanical loads isn't changed either.

The results showed a significant reduction in the rate of total corrosion (about 35\%) and anomalous de-intensification of the local content of corrosion processes (by 500\%). Such corrosive behavior once again confirms the discovery of a specific ratio of ionic concentrations of soil electrolyte, which is extremely dangerous for steel pipelines.

Dependences of the pipe wall thinning are similar to those which were stated for the non-acidified environment with the earlier mentioned decrease of the corrosion intensity decline, according to the change of the ionic concentrations.

To have a better assessment of the relative corrosion activity of soil electrolytes and the measure of operational risks, it is suggested to present the collected material as integrated corrosion decline curves (Fig. 5) and pipe wall thinning diagrams (Fig. 6).

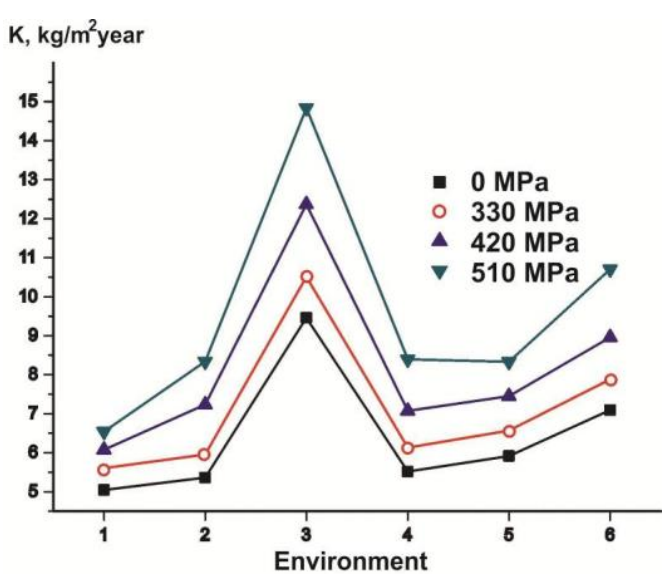

a

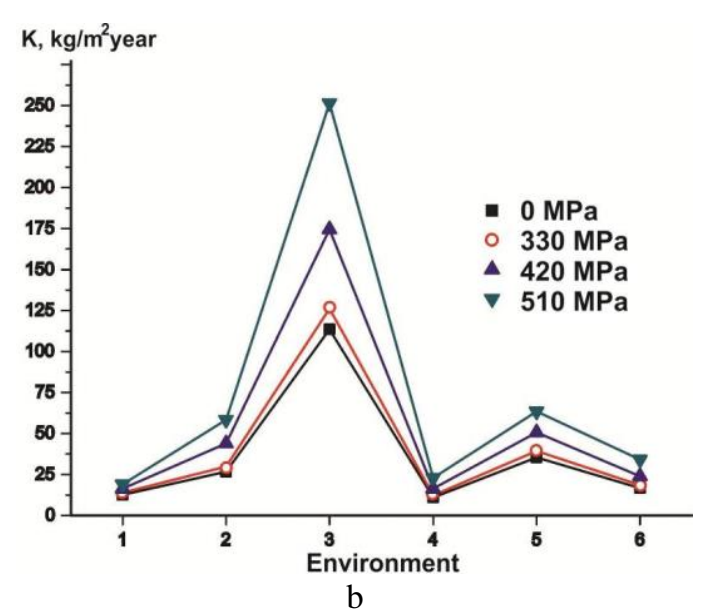

Figure 5. Integrated diagram of pipeline steel corrosion speed ( $\mathrm{a}$ - general corrosion, $\mathrm{b}$ - local corrosion) 
This methodological approach will allow determining the sequence and frequency of planned and unscheduled check over and remedial maintenance. This technology is based on highlighting the pipeline sections, which are located in the most dangerous corrosive soils, with the help of obtained diagrams and to optimize the operating modes in order to minimize corrosion intensification by mechanical factor.

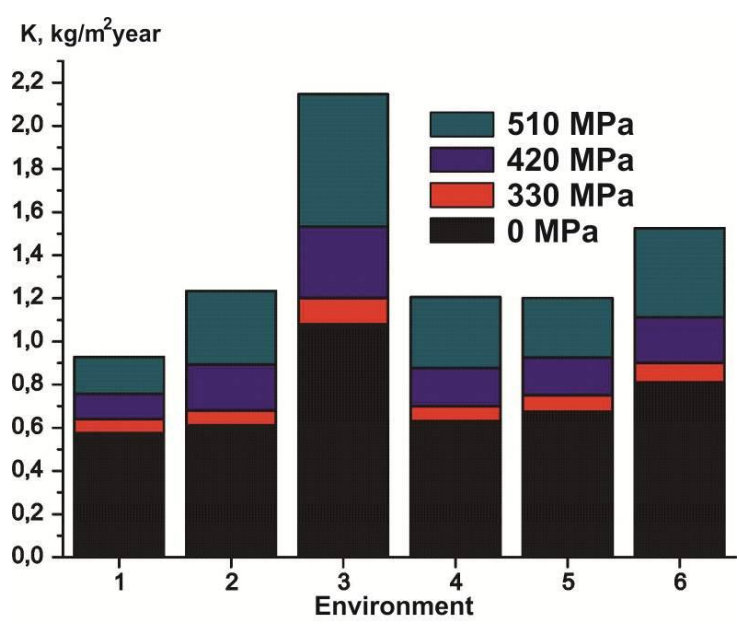

a

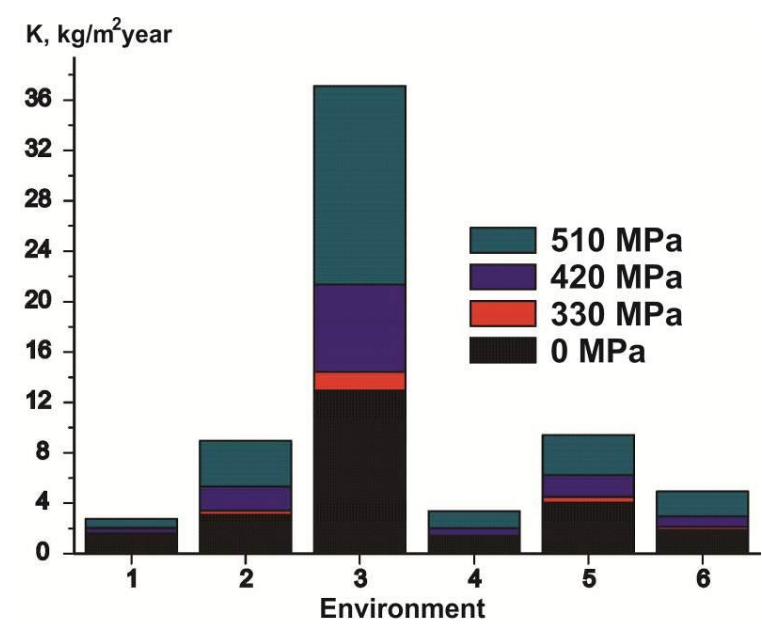

b

Figure 6. Integrated diagram of thinning of the pipeline wall ( $\mathrm{a}$ - with general corrosion processes, $\mathrm{b}$ - with local corrosion processes)

The follow-on revision and development of the proposed methodological approaches into the completed engineering methodology will allow correct assessment of the operational risks associated with environmental corrosion and the development of scientifically wellgrounded preventive measures for probable failure occurrence.

Conclusions. An anomalous increase in the soil electrolyte corrosive activity was detected due to the synergistic cumulative action of the corrosion-active components present in determined ratios of ionic molar concentrations. The usage of joint corrosion decline diagrams of the pipeline steel and the thinning of the wall will help identify the most dangerous pipeline sections and develop appropriate preventive operations. The obtained results allow us to better evaluate operational risks and to predict the life length and usable lifespan of the safe oil and gas pipeline operation, as well as to prevent a significant number of pipeline failures at the engineering design and production activity.

\section{References}

1. Honcharuk M. I., Kryzhanivskyy YE. I., Poberezhnyy L. YA. Koroziyno-vlasne povedinka metalevoho hazoprovodu. Naukovyy visnyk Natsionalnoho tekhnichnoho universytetu Nafty i Hazu. 2003. № 1 (5). P. 54-59. [In Ukraine].

2. Poberezhnyi L. Y., Marushchak P. O., Sorochak A. P., Draganovska D., Hrytsanchuk A. V., Mishchuk B. V. Corrosive and mechanical degradation of pipelines in acid soils. Strength of Materials. 2017. 49 (4). P. 539-549. https://doi.org/10.1007/s11223-017-9897-x

3. Nykyforchyn H. M., Tsyrul'nyk O. T., Petryna D. Y., Hredil' M. I. Degradation of steels used in gas main pipelines during their 40-year operation. Strength of materials. 2009. 41 (5). P. 501-505. https://doi.org/10.1007/s11223-009-9158-8

4. Zeng Y. M., Luo J. L. Electronic band structure of passive film on X70 pipeline steel. Electrochimica acta. 2003. 48 (23). P. 3551-3562. https://doi.org/10.1016/S0013-4686(03)00477-8

5. Bonnel A., Dabosi F., Deslouis C., Duprat M., Keddam M., Tribollet B. Corrosion study of a carbon steel in neutral chloride solutions by impedance techniques. Journal of the Electrochemical Society. 1983. 130 (4). P. 753-761. https://doi.org/10.1149/1.2119799 
6. Zvirko O. I., Mytsyk A. B., Tsyrulnyk O. T., Gabetta G., Nykyforchyn H. M. Corrosion degradation of steel of long-term operated gas pipeline elbow with large-scale delamination. Materials Science. 2017. 52 (6). P. 861-865. https://doi.org/10.1007/s11003-017-0032-8

7. Kryzhanivskyy YE. I., Poberezhnyy L. YA. Metodolohiya doslidzhennya deformatsiy ta ruynuvannya truboprovidnykh system: materialy III mizhnarodnoyi konferentsiyi "Mekhanika ruynuvannya ta identychnosti konstruktsiy". Lviv, 2004. P. 419-424. [In Ukraine].

8. Poberezhnyy L. YA. Koroziya pidzemnykh mahistralnykh truboprovodiv. Rozdilennya ta rozsypka naftovykh i hazovykh rodovyshch. 2005. № 2 (15). P. 27-31. [In Ukraine].

9. Poberezhnyy L. YA. Koroziyno-faktychna dehradatsiya mahistralnykh hazoprovodiv. Naftova i hazova promyslovist. 2011. № 1. P. 36-38. [In Ukraine].

10. Poberezhnyy L. YA. Elektrokhimichna povedinka z vykorystannyam naftohazoprovidnykiv u khlorydnykh ta khlorydno-sulfatnykh potrebakh. Visnyk Skhidnoukrayinskoho natsionalnoho universytetu imeni V. Dalya. 2007. № 9 (115). P. 276-284. [In Ukraine].

\title{
Список використаної літератури
}

1. Гончарук М. І., Крижанівський С. І., Побережний Л. Я. Корозійно-механічна поведінка металу газопроводу. Науковий вісник ІФНТУНГ. 2003. № 1. С. 54-59.

2. Poberezhnyi L. Y., Marushchak P. O., $\quad$ Sorochak A. P., Draganovska D., Hrytsanchuk A. V., Mishchuk B. V. Corrosive and mechanical degradation of pipelines in acid soils. Strength of Materials. 2017. 49 (4). P. 539-549. https://doi.org/10.1007/s11223-017-9897-x

3. Nykyforchyn H. M., Tsyrul'nyk O. T., Petryna D. Y., Hredil' M. I. Degradation of steels used in gas main pipelines during their 40-year operation. Strength of materials. 2009. 41(5). P. 501-505. https://doi.org/10.1007/s11223-009-9158-8

4. Zeng Y. M., Luo J. L. Electronic band structure of passive film on X70 pipeline steel. Electrochimica acta. 2003. 48 (23). P. 3551-3562. https://doi.org/10.1016/S0013-4686(03)00477-8

5. Bonnel A., Dabosi F., Deslouis C., Duprat M., Keddam M., Tribollet B. Corrosion study of a carbon steel in neutral chloride solutions by impedance techniques. Journal of the Electrochemical Society. 1983. 130 (4). P. 753-761. https://doi.org/10.1149/1.2119799

6. Zvirko O. I., Mytsyk A. B., Tsyrulnyk O. T., Gabetta G., Nykyforchyn H. M. Corrosion degradation of steel of long-term operated gas pipeline elbow with large-scale delamination. Materials Science. 2017. 52 (6). Р. 861-865. https://doi.org/10.1007/s11003-017-0032-8

7. Крижанівський Є. І., Побережний Л. Я. Методологія дослідження деформації та руйнування трубопровідних систем: матеріали III міжнародної конференції «Механіка руйнування матеріалів і міцність конструкцій». Львів, 2004. С. 419-424.

8. Побережний Л. Я. Корозія підземних магістральних трубопроводів. Розвідка та розробка нафтових і газових родовищ. 2005. № 2 (15). С. 27-31.

9. Побережний Л. Я. Корозійно-механічна деградація магістральних газопроводів. Нафтова і газова промисловість. 2011. № 1. С. 36-38.

10. Побережний Л. Я. Електрохімічна поведінка матеріалу нафтогазопроводів у хлоридних та хлоридно-сульфатних середовищах. Вісник Східноукраїнського національного університету імені В. Даля. 2007. № 9 (115). С. 276-284

\section{УДК 620.179}

\section{ВПЛИВ РІВНЯ РН НА КОРОЗІЮ ГАЗОПРОВОДІВ У ГРУНТАХ ІЗ ВИСОКОЮ МІНЕРАЛІЗАЦІЕЮ}

\section{Любомир Побережний; Андрій Грицанчук; Наталія Галушко; Любов Побережна}

\author{
Івано-Франківський національний технічний університет нафти і газу, \\ Івано-Франківськ, Україна
}

Резюме. В практиці будівництва питання взасмодіі трубопроводів з трунтом вивчені недостатньо. Тому чітких і апробованих рімень щзодо вибору чи визначення основних характеристик для 
розрахунку та аналізу роботи підземних трубопроводів немає. Об'єктом досліджень вибрано підземні магістральні трубопроводи, при будівниџтві яких використовувалися труби зі сталі 17Г1СУ. Мета роботи - встановлення закономірностей корозії підземних газопроводів у високомінералізованих грунтах із різним рівнем рН. Дослідження показали зростаючу інтенсивність корозійної деградації в усіх трьох середовищах як для загальної, так і локальної корозії. Такі результати добре узгоджуються з отриманими під час електрохімічних випробовувань значеннями струмів корозії анодного та катодного розчинення, а також кінетикою електродного потенціалу. Зі збільшенням йонної сили швидкості загальної та локальної корозї зростають, причому особливо характерно иее спостерігається при переході від МС2 до МС3. Можемо констатувати, щзо вперше виявлено співвідношення йонних концентрацій, за якого синергічна дія сульфат та хлорид йонів є настільки кумулятивною. Оцінювання локалізації корозійних процесів у всіх хлоридно-сульфатних МС показало значний ступінь локалізації, однак у МСз знову спостерігалася аномальна корозійна поведінка. Вперше виявлено не лише аномально високу швидкість корозії при даному співвідношенні йонних концентрацій, а й аномально інтенсивну локалізацію корозійних процесів. 3 метою кращчого оцінювання відносної корозійної активності трунтових електролітів та ступеня експлуатаџійних ризиків у них запропоновано нагромаджений матеріал представляти у вигляді об'єднаних кривих корозійної деградації та діаграм утоншення стінки труби. Отримані результати дадуть змогу краще оцінити експлуатаційні ризики та прогнозувати ресурс $і$ залишковий ресурс безпечної експлуатації нафтогазопроводів, а також попередити значну кількість відмов трубопроводів на стадіях проектування та експлуатаціiі.

Ключові слова: газопровід, корозійна деградація, ивидкість корозії, високомінералізовані грунти, кислотність грунту. 